\title{
KESENJANGAN KINERJA ABK KAPAL PATROLI KESATUAN PENJAGAAN LAUT DAN PANTAI (KPLP) TANJUNG PERAK SURABAYA
}

\author{
Gap Performance of Crew KPLP Patrol Boat, Tanjung Perak Surabaya
}

Oleh:

\author{
Rd. Rara Meita Angling Dewi ${ }^{*}$, Parulian Hutagaol², Deni Achmad Soeboer ${ }^{3}$ \\ ${ }^{1}$ Mahasiswa Sekolah Bisnis, Institut Pertanian Bogor \\ 2 Departemen Ilmu Ekonomi, Fakultas Ekonomi dan Manajemen-IPB \\ ${ }^{3}$ Departemen Pemanfaatan Sumberdaya Perikanan, Fakultas Perikanan dan Ilmu Kelautan- \\ $I P B$ \\ *Korespondensi: w_meita@yahoo.com
}

\begin{abstract}
ABSTRAK
Dalam rangka mewujudkan keamanan laut Indonesia, maka Kapal Patroli Pangkalan PLP Tanjung Perak Surabaya memiliki tugas dan tanggung jawab yang sangat besar, diperlukan kinerja ABK yang baik untuk mencapai tujuan tersebut. Menurut Laporan Kinerja Pelabuhan (LAKIP 2016), bahwa capaian kinerja ABK Kapal Patroli masih di bawah target kinerja yang diharapkan. Tujuan penelitian ini untuk menghitung capaian kinerja dan kesenjangan aktual ABK Kapal Patrolii KPLP Tanjung Perak Surabaya. Aspek yang digunakan dalam penelitian ini adalah sumberdaya manusia, sarana dan prasarana, tata kelola/manajemen pengolalaan operasi dan dana yang tersedia. Kemudian dari data tersebut dibuat dalam skala Lykert dan selanjutnya dilakukan analisis kesenjangan antara kinerja aktual dengan standar kinerja yang ditetapkan. Hasil penelitian menunjukkan bahwa terjadi kesenjangan kinerja sebesar $12 \%$ dari standar kinerja yang diharapkan.
\end{abstract}

Kata kunci: Analisis Kesenjangan, Kinerja ABK Kapal Patroli KPLP, Skala Lykert.

\section{ABSTRACT}

In order to realize the maritime security of Indonesia, the Patrol Boat Pangkalan PLP Tanjung Perak Surabaya has a very large duties and responsibilities, so it needs a very high performance $A B K$ to achieve that goal. According to Port Performance Report (LAKIP 2016), the performance of ABK Patrol Ship has decreased its performance. The objective of this research was to calculate actual performance gap of crew KPLP Patrol Boat in Tanjung Perak Surabaya. The calculation was based on several factors that affect the decreasing performance, among others human resources, facilities and infrastructure, governance management / management and available funds. Lykert scale method was used and then gap analysis was applied to calculate performance between actual and a set of performance standard. The results showed that there was a performance gap of $12 \%$ of the established performance standards.

Keywords: Crew performance of KPLP Patrol Boat, Gap Analysis, Lykert Scale.

\section{PENDAHULUAN}

Pelabuhan merupakan tempat untuk memberikan pelayanan sandar dan labuh sebuah kapal, selain itu memberikan pelayanan bongkar dan muat barang ataupun penumpang. Namun selain tugas dan fungsinya seperti disebutkan di atas, pelabuhan juga diwajibkan untuk memberikan rasa nyaman dan keamanan bagi kapal-kapal yang akan masuk dan keluar pelabuhan tersebut. Hal ini telah 
tertuang dalam Undang-Undang No 17 Tahun 2008 tentang Pelayaran pada pasal 276 ditegaskan, bahwa pentingnya keselamatan dan keamanan berlayar serta kelancaran berlalu lintas di perairan tertentu dan pelabuhan. Peran sebagai penjaga laut dan pantai untuk memberikan rasa selamat dan aman diemban oleh Kesatuan Penjaga Laut dan Pantai (KPLP) dengan tugasnya adalah 1) melakukan pengawasan keselamatan dan keamanan pelayaran; 2) melakukan pengawasan, pencegahan, dan penanggulangan pencemaran di laut; 3) pengawasan dan penertiban kegiatan serta lalu lintas kapal; 4) pengawasan dan penertiban kegiatan salvage, pekerjaan bawah air, serta eksplorasi dan eksploitasi kekayaan laut; 5) pengamanan Sarana Bantu Navigasi-Pelayaran; 6) mendukung pelaksanaan kegiatan pencarian dan pertolongan jiwa di laut.

Luasnya daerah wilayah kerja pelabuhan Tanjung Perak (termasuk Alur Pelayaran Barat dan Timur Surabaya) membutuhkan kinerja aparat yang baik untuk menjamin keselamatan dan keamanan pelayaran di perairan tersebut. Beberapa laporan tentang hasil kinerja Kesatuan Penjaga Laut dan Pantai (KPLP) yang seharusnya mengawal keamanan dan keselamatan di wilayah perairan Pelabuhan Tanjung Perak dianggap tidak melakukan kinjerjanya dengan baik (LAKIP, 2016). Mengacu pada laporan capaian kinerja ABK kapal patroli KPLP tersebut, maka perlu diidentifikasi faktor-faktor yang yang mempengaruhi menurunnya kinerja ABK Kapal Patroli serta mencari tahu seberapa jauh kesenjangan yang terjadi antara kinerja aktual terhadap standar kinerja yang harapkan.

\section{METODE PENELITIAN}

Objek yang digunakan dalam penelitian adalah Anak Buah Kapal (ABK) Kapal Patroli KPLP Tanjung Perak Surabaya yang berjumlah 165 orang sampel. Penentuan sampel menggunakan cara purposive sampling. Kinerja ABK Kapal Patroli ditinjau dari 4 (empat) aspek yaitu:

A. Aspek Sumberdaya Manusianya yang meliputi 4 (empat) dimensi, terdiri dari:

1) dimensi kecakapan meliputi: pendidikan formal, pendidikan keahlian, pengetahuan tugas, pelaksanaan tugas, dan penguasaan tugas;

2) dimensi keseriusan meliputi: prioritas kerja, proaktif, adaptif terhadap peraturan baru;

3) dimensi ketelitian terdiri dari: Perhitungan, Inovatif, cekatan, taat kepada peraturan dan SOP; dan

4) dimensi kemampuan manajemennya meliputi: struktur organisasi, pendelegasian, bekerja secara tim.

B. Aspek Sarana dan Prasarana yang meliputi 3(tiga) dimensi, yaitu:

1) dimensi kualitas dan kuantitas meliputi: kesesuaian sarana, faktor pendukung, kesesuaian prasarana;

2) dimensi pengadaan meliputi: spesifikasi, karakteristik, kebijakan, ketersediaan;

3) dimensi pemeliharaan dan perawatan terdiri dari: kemudahan, berkala, pembagian tugas, sumbangsih;

C. Aspek Anggaran terdiri dari 2 (dua) dimensi yaitu:

1) dimensi pendapatan $A B K$ yang terdiri dari: kesesuaian, tuntutan pekerjaan, reward, resiko pekerjaan, motivasi, rasa syukur;

2) dimensi pengadaan meliputi: kecukupan, kesepakatan, transparansi, keikutsertaan, efektivitas, dan kebutuhan.

D. Aspek Tata kelola terdiri dari 4 (empat) dimensi yaitu:

1) dimensi Perencanaan meliputi: keikutsertaan, SOP, mempermudah, kedetailan, koordinasi;

2) dimensi pengorganisasian terdiri dari: koordinasi, penunjukan, kesesuaian, tujuan akhir;

3) dimensi pelaksanaan meliputi: kesamaan, kepatuhan, kreativitas, optimal, SOP, realisasi; dan

4) dimensi pengawasan dan pengendalian meliputi: keseriusan, manfaat, dampak, sarana, tujuan untuk mendapatkan data tersebut digunakan kuisioner. 
Data hasil kuesioner dari ke 4 aspek kemudian masing-masing berdasarkan dimensinya dibuat dalam Skala Lykert yaitu (1) sangat tidak setuju (2) tidak setuju (3) kurang setuju (4) setuju (5) sangat setuju, kemudian dianalisa kesenjangannya dalam bentuk persentase rata-rata dari masing-masing aspek untuk dianalisa secara kuantitatif kemudian didapatkan hasil gabungan rata-rata persentase dari semua aspek untuk didapatkan kesenjangan kinerjanya.

\section{HASIL DAN PEMBAHASAN}

Hasil analisis kesenjangan dari setiap aspek beserta dimensi ABK Kapal Patroli KPLP Tanjung Perak menggunakan Skala Lykert didapat sebagai berikut:

\section{Aspek Sumberdaya Manusia (SDM)}

Persentase rata-rata capaian kinerja berdasarkan dimensi kecakapan memperlihatkan bahwa faktor pendidikan dan keahlian sudah memadai sesuai dengan bidang kerjanya, hal ini ditunjukan dengan angka capaian $94,8 \%$ dan $91,6 \%$. Namun ketika melaksanakan tugas masih kurang dari sisi pengetahuan dan penguasaan tugasnya, hal ini dapat ditunjukan dengan capaian kinerjanya berturutturut $87,8 \%, 86,6 \%$, dan 86,6\%. Secara keseluruhan capaian kinerja dari deimensi kecakapan mempunyai nilai rata-rata sebesar $89,5 \%$.

Persentase rata-rata capaian kinerja berdasarkan dimensi keseriusan faktor prioritas kerja mempunyai nilai yang cukup tinggi yaitu 90,6\%, hal ini sudah memperlihatkan keseriusan dalam memprioritaskan pekerjaannya. Namun belum menunjukan keaktivan secara mandiri dan masih rendah dalam menerima aturan-aturan baru, hal ini terlihat dari nilai yang ditunjukkan sebesar $80,8 \%$ dan $84,4 \%$. Secara keseluruhan capaian kinerja dari deimensi keseriusan mempunyai nilai ratarata sebesar $85,3 \%$.

Persentase rata-rata capaian kinerja berdasarkan dimensi ketelitian faktor Inovatif dan Perhitungan mempunyai nilai yang cukup tinggi yaitu $90,4 \%$, dan $89,6 \%$ hal ini sudah memperlihatkan ketelitian dalam membangun pekerjaannya. Namun belum menunjukan cekatan secara mandiri dan masih rendah dalam mentaati aturan-aturan dan SOP, hal ini terlihat dari nilai yang ditunjukkan sebesar $80,8 \%$ dan $84,4 \%$. Secara keseluruhan capaian kinerja dari deimensi ketelitian mempunyai nilai rata-rata sebesar $88,5 \%$.

Persentase rata-rata capaian kinerja berdasarkan dimensi kemampuan manajemen faktor bekerjasama secara team dan pemahaman terhadap struktur organisasi sudah cukup tinggi yaitu $92,2 \%$ dan $91,4 \%$, hal ini telah menunjukan kemampuannya dalam mengelola pekerjaannya. Namun masih masih lemah dalam pendelegasian hanya mempunyai nilai $85,8 \%$

Persentase rata-rata kesenjangan gabungan aspek SDM berdasarkan dimensi kecakapan, dimensi keseriusan, dimensi ketelitian, dan dimensi kemampuan manajemen adalah sebesar 11,7\%. Faktor terbesar yang membuat kesenjangan kinerja mejadi kecil adalah faktor kemampuan manajemen yaitu 10,2\%.

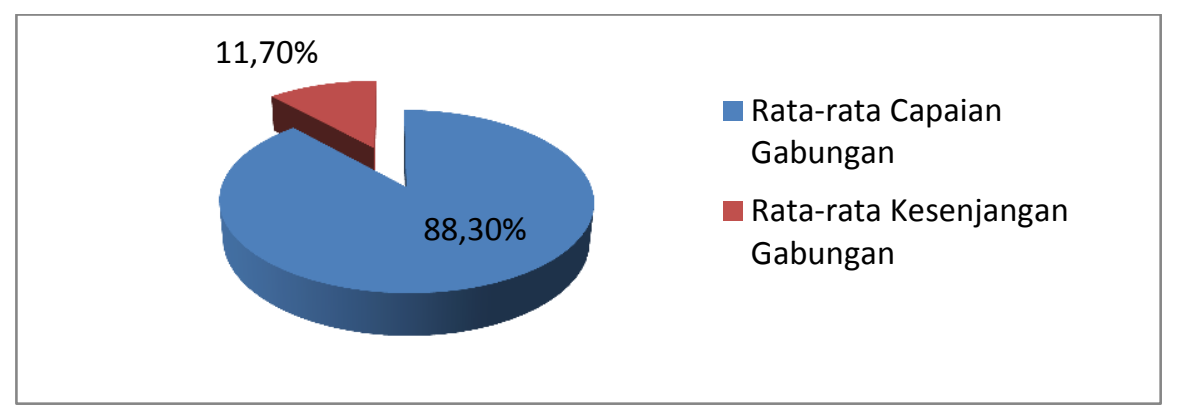

Gambar 1. Capaian dan Kesenjangan kinerja pada aspek SDM 


\section{Aspek Sarana dan Prasarana}

Persentase rata-rata capaian kinerja berdasarkan dimensi kualitas dan kuantitas, kesesuaian sarana merupakan faktor tertinggi dalam capaian kinerja yaitu sebesar $89,4 \%$. Sedangkan untuk faktor pendukung dan faktor kesesuaian prasarana sedikit di bawah faktor kesesuaian sarana yaitu berturut-turut sebasar $88,4 \%$ dan $86,4 \%$, secara keseluruhan rata-rata kinerja capaian kinerja dari dimensi kualitas dan kuantitas menjadi $88,1 \%$.

Persentase rata-rata capaian kinerja berdasarkan dimensi pengadaan, faktor telaah terhadap spesifikasi barang mempunyai nilai sebesar $88,6 \%$. Sedangkan untuk karakteristik dan ketersediaan sedikit di bawah spesifikasi barang yaitu berturut-turut sebesar $88,4 \%$ dan $87,4 \%$. Namun masih lemah dalam kebijakan hanya mempunyai nilai $86,8 \%$. Secara keseluruhan rata-rata capaian kinerja dari dimensi pengadaan menjadi 87,8\%.

Persentase rata-rata capaian kinerja berdasarkan dimensi pemeliharaan dan perawatan, faktor sumbangsih memiliki nilai tertinggi yaitu $91 \%$. Sedangkan untuk faktor kemudahan dan pembagian tugas keduanya mempunyai nilai yang sama yaitu 90,4\%. Untuk faktor berkala mempunyai nilai terendah dibandingkan dengan yang lainnya hanya mencapai nilai sebesar $87 \%$. Secara keseluruhan rata-rata capaian kinerja dari dimensi pemeliharaan dan perawatan menjadi 98,7\%.

Persentase rata-rata kesenjangan gabungan dari aspek sarana dan prasarana berdasarkan dimensi kualitas dan kuantitas, pengadaan, pemeliharaan dan perawatan adalah sebesar $11,5 \%$. Faktor terbesar yang membuat kesenjangan kinerja menjadi kecil adalah dari faktor pemeliharaan dan perawatan yaitu sebesar $10,3 \%$.

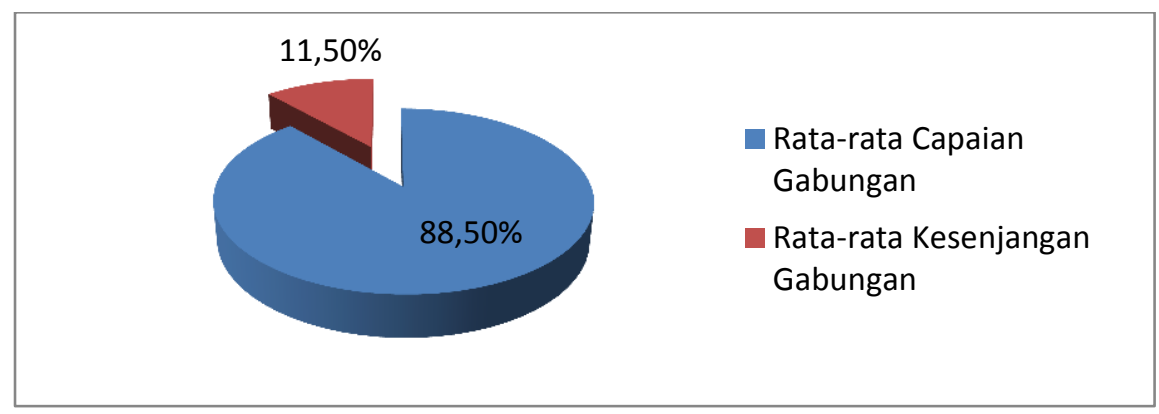

Gambar 2. Capaian dan Kesenjangan kinerja pada aspek sarana dan prasarana

\section{Aspek Anggaran}

Persentase rata-rata capaian kinerja berdasarkan dimensi pendapatan ABK, faktor kesesuaian memiliki nilai tertinggi yaitu sebesar 90,6\%, kemudian secara berturut-turut diikuti oleh faktor tuntutan pekerjaan sebesar $88,2 \%$, faktor reward $87,2 \%$ dan faktor resiko pekerjaan $87 \%$. Sedangkan faktor motivasi sebesar $86,6 \%$ dan faktor rasa syukur dengan nilai $86,2 \%$ merupakan nilai terendah pada dimensi pendapatan ABK. Secara keseluruhan rata-rata capaian kinerja dari dimensi pendapatan ABK menjadi 87,6\%.

Persentase rata-rata capaian kinerja berdasarkan dimensi pengadaan, faktor kesepakatan menunjukan nilai tertinggi dibandingkan dengan lainnya yaitu mencapai nilai sebesar $89,4 \%$, kemudian diikuti oleh faktor transparansi $88 \%$, faktor efektivitas $87,6 \%$, serta faktor keikutsertaan $87,4 \%$. Sedangkan untuk dua terbawah yaitu faktor kecukupan $87 \%$ dan faktor kebutuhan sebesar $85,4 \%$. Secara keselutuhan rata-rata capaian kinerja dari dimensi pengadaan menjadi sebesar $87,5 \%$.

Persentase rata-rata kesenjangan kinerja gabungan aspek anggaran berdasarkan dimensi pendapatan $\mathrm{ABK}$ dan dimensi kebijakan adalah sebesar 12,5\%. Faktor yang membuat kesenjangan adalah faktor pendapatan ABK sebesar 12,4\%. 


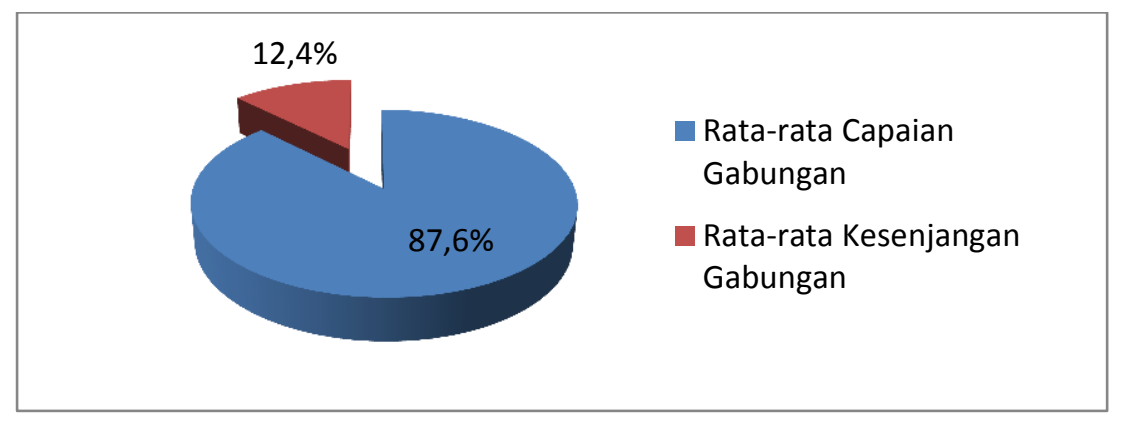

Gambar 3. Capaian dan Kesenjangan kinerja pada aspek anggaran

\section{Aspek Tata Kelola}

Persentase rata-rata capaian kinerja berdasarkan dimensi perencanaan, faktor koordinasi mempunyai sumbangsih terbesar yaitu $88,8 \%$. Selanjutnya diikuti oleh faktor keikutsertaan $87,6 \%$, faktor kedetailan $87 \%$ dan mempermudah $86,6 \%$, akan tetapi untuk SOP menunjukan nilai yang rendah jika dibandingkan dengan lainnya yaitu hanya $86,4 \%$. Secara keseluruhan capaian kinerja dari dimensi perencanaan mempunyai nilai rata-rata sebesar $87,3 \%$.

Persentase rata-rata capaian kinerja berdasarkan dimensi pengorganisasian, faktor koordinasi mempunyai nilai tertinggi yaitu $88,8 \%$, setelahnya faktor penunjukkan $88,4 \%$, faktor kesesuian $87,8 \%$. Faktor tujuan akhir sebesar $87,6 \%$ merupakan nilai terendah yang didapat pada dimensi pengorganisasian. Secara keseluruhan rata-rata capaian kinerja dari dimensi pengorganisasian mempunyai nilai rata-rata sebesar $85,3 \%$.

Persentase rata-rata capaian kinerja berdasarkan dimensi pelaksanaan pada faktor kepatuhan memperoleh hasil tertinggi yaitu $88 \%$, kemudian diikuti oleh faktor kreativitas $87,8 \%$, faktor SOP $87,8 \%$, faktor optimal $87,2 \%$, dan faktor realisasi merupakan faktor yang terkecil capaiannya yaitu sebesar $85,8 \%$. Secara keseluruhan capaian kinerja dari dimensi pelaksanaan mempunyai nilai ratarata sebesar $87,4 \%$.

Persentase rata-rata capaian kinerja berdasarkan dimensi pengawasan dan pengendalian, faktor berkala menjadi faktor tertinggi capaiannya yaitu sebesar $87,8 \%$, kemudian diikuti faktor manfaat dan faktor tujuan berturut-turut $86,8 \%$ dan $86,6 \%$. Skor terendah yang pada dimensi ini diraih oleh faktor dampak dengan nilai $85,4 \%$. Secara keseluruhan rata-rata capaian kinerja dari dimensi pengawasan dan pengendalian adalah sebesar $86,7 \%$.

Persentase rata-rata kesenjangan gabungan aspek tata kelola berdasarkan dimensi perencanaan, dimensi pengorganisasian, dimensi pengawasan dan pengendalian adalah sebesar 12,6\%. Faktor terbesar yang membuat kesenjangan kinerja mejadi kecil adalah faktor perngorganisasian yaitu $11,9 \%$.

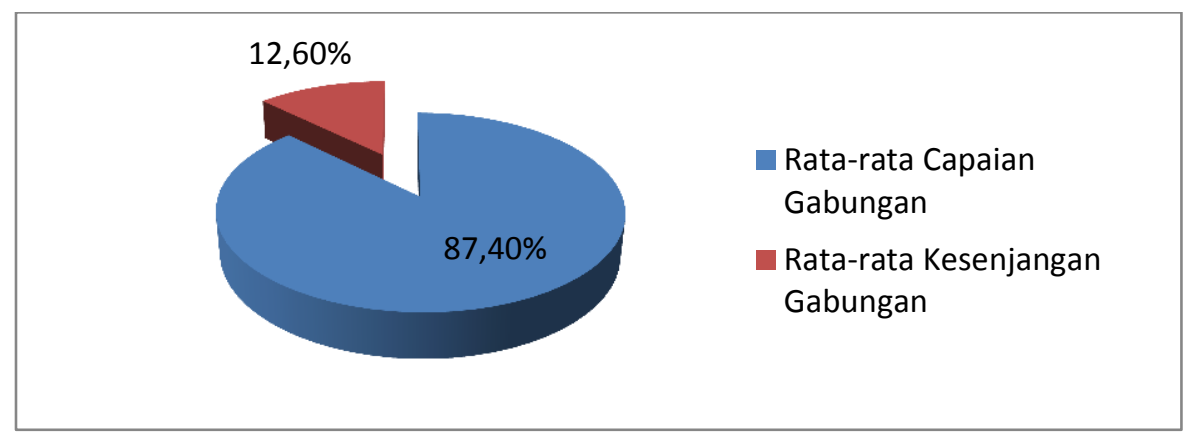

Gambar 4. Capaian dan Kesenjangan kinerja pada aspek tata kelola 
Persentase rata-rata kesenjangan kinerja gabungan berdasarkan aspek SDM, aspek sarana dan prasarana, aspek anggaran, aspek tata kelola adalah sebesar 12\%. Aspek yang membuat kesenjangan kinerja menjadi kecil adalah dari aspek sarana dan prasaran sebesar 11,5\%.

Tabel 1. Persentase rata-rata capaian dan kesenjangan kinerja gabungan berdasarkan keempat aspek yang diteliti

\begin{tabular}{clcc}
\hline No. & Aspek & \% rata-rata capaian & $\begin{array}{c}\text { \% rata-rata } \\
\text { Kesenjangan }\end{array}$ \\
\hline 1 & SDM & 88.3 & 11.7 \\
2 & Sarana Prasarana & 88.5 & 11.5 \\
3 & Anggaran & 87.6 & 12.4 \\
4 & Tata Kelola & 87.3 & 12.7 \\
\hline & & $\mathbf{8 8 . 0}$ & $\mathbf{1 2 . 0}$ \\
\hline
\end{tabular}

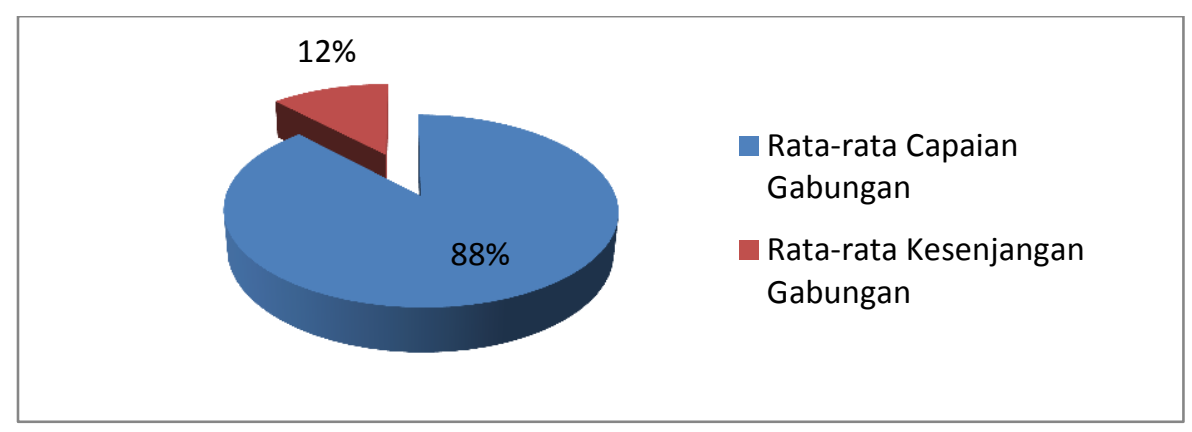

Gambar 5. Capaian dan Kesenjangan kinerja gabungan pada semua Aspek

\section{KESIMPULAN}

1. Empat aspek yang digunakan dalam penelitian ini telah dapat digunakan untuk menghitung kesenjangan kinerja ABK Kapal Patroli KPLP di Tanjung Perak.

2. Kesenjangan rata-rata diperoleh sebesar $12 \%$, yang menunjukkan kinerja masih dibawah standar yang telah ditetapkan.

\section{DAFTAR PUSTAKA}

Arifin, Anwar. 1994. Strategi Komunikasi, Sebuah Pengantar Ringkas. CV. ARMICO. Bandung

Bambang Suwarto. 2014. Tarik Ulur Penjaga Laut dan Pantai, Jurnal Maritim, Jakarta.

Bernardin, H. John and Russell, Joyce E. A. 2003. Human Resource Management, Ney York : Me Graw-Hill Inc.

Handoko, T. Hani. 2012, Manajemen Personalia dan Sumber Daya Manusia. Yogyakarta: BPFE.

Hasibuan, Malayu. 2013. Manajemen Personalia dan Sumber Daya Manusia, Jakarta : Bumi Aksara.

Hasibuan. 2010. Manajemen Sumber Daya Manusia. Bumi Aksara. Jakarta.

Keputusan Direktur Jenderal Perhubungan Laut Nomor UM.008/100/19/DJPL-15 Tentang Rencana Strategis (RENSTRA) Direktorat Jenderal Perhubungan Laut Tahun 2015-2019. Jakarta

Keputusan Menteri Perhubungan Indonesia Nomor KP 901 TAHUN 2016 tentang Rencana Induk Pelabuhan Nasional. 
Kusriyanto, Bambang. 2005. Kinerja Karyawan. Yogyakarta: Badan Penerbit Fakultas Ekonomi (BPFE).

Laporan Kinerja Instansi Pemerintah (LAKIP). 2016. Direktorat Jenderal Perhubungan Laut Kementerian Perhubungan. Jakarta.

Noe, R.A., Hollenbeck, J.R., Gerhart, B. and Wright, P.M. 2010. Human Resource Management: Gaining a Competitive Advantage, New York: McGraw Hill.

Putra, I Wayan Indra, Suwendra, I Wayan, Bagia, I Wayan. 2016. Pengaruh Tingkat Pendidikan dan Disiplin Kerja Terhadap Kinerja Karyawan. e-Journal Bisma Universitas Pendidikan Ganesha Jurusan Manajemen. Volume 4.

Retno Setyowati dan Muhammad Mathori. 2016, Analisis Kualitas Sumber Dana Manusia di Badan Pengawasan keuangan dan Pembangunan (BPKP), Jurnal Riset Manajemen, Volume 3 : No. 2, Juli 2016, $174-189$.

Ridwan. 2007. Skala Pengukuran Variabel-variabel Penelitian, Alfabeta, Bandung.

Rivai, Veithzal. 2013. Manajemen Sumber Daya Manusia Untuk Perusahaan. PT. Raja Grafindo Persada, Jakarta.

Robbins, P. Stephen dan Timothy A., Judge. 2008. Perilaku Organisasi, Organizational Behaviour. Edisi 12, Jakarta : Salemba Empat.

Ruky, Achmad S. 2006. Sistem Manajemen Kinerja, Jakarta : PT Gramedia Pustaka Utama.

Safitri, Erma. 2013. Pengaruh Pelatihan dan Disiplin Kerja Terhadap Kinerja Karyawan. Jurnal Ilmiah Manajemen. Volume 1 Nomor 4.

Sah. A. K.. 2001. Systems Approach to Training and Development. New Delhi: Sterling Publishers Pvt. Ltd.

Sastrohadiwaryo, Siswanto. 2002. Manajemen Tenaga Kerja Indonesia Pendekatan Administratif dan Operasional. Cetakan kesatu. Bumi Aksara, Jakarta.

Shakeel, Sidra dan Lodhi, Samreen. 2015. Impact of Training and Development on Employee Performance: A Case of Banking Sector of Pakistan. Journal of Resources Development and Management. Vol. 14.

Siagian, Sondang P. 2009. Manajemen Sumber Daya Manusia, Cetakan Kesepuluh, Jakarta : Bumi Aksara.

Simanjuntak, Payaman J. 2000. Produktivitas tenaga Kerja, Grafindo, Jakarta

Sugiyono. 2012. Metode Penelitian Kuantitatif, Kualitatif dan R\&D. Bandung: Alfabeta.

Suhendi, Hendi. Dan Sahya Anggara. 2010. Perilaku Organisasi. CV. Pustaka Setia. Bandung.

Tahir, Neelam. 2014. The Impact of Training and Development on Employees Performance and Productivity A case study of United Bank Limited Peshawar City, KPK, Pakistan. International Journal of Academic Research in Business and Social Sciences. Vol. 4, No. 4

Thaief, Ilham, Baharuddin, Aris, Priyono dan Idrus, Mohamad Syafi'i. 2015. Effect of Training, Compensation and Work Discipline against Employee Job Performance (Studies in the Office of PT. PLN (Persero) Service Area and Network Malang). Review of European Studies; Vol. 7, No. 11.

Undang-Undang Republik Indonesia Nomor 17 Tahun 2008 Tentang Pelayaran. 
Yakub, Suardi, Tulim, Anto, Suharsi. 2014. Pengaruh Disiplin Kerja, Pendidikan Dan Pelatihan Terhadap Kinerja Pegawai Pada PT Kertas Kraft Aceh (Persero). Jurnal Ilmiah Saintikom. STMIK Triguna Dharma, Medan. 